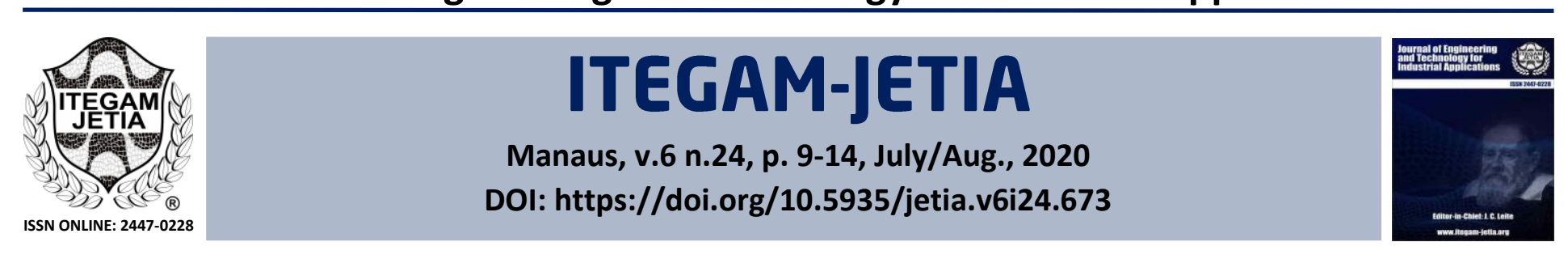

\title{
ASSESSMENTS AND EXPERTISE OF THE PATHOLOGICAL MANIFESTATIONS OF A RESIDENTIAL COMPLEX LOCATED IN THE SQUARE 14 OF JANUARY NEIGHBORHOOD IN THE CITY OF MANAUS
}

\author{
José Basílio da Silva Filho', Robson Edgar Faria², Darlei dos Anjos Lavor³, Antônio Estanislau Sanches ${ }^{4}$ \\ and David Barbosa de Alencar ${ }^{5}$
}

1,2 Blauro Cardoso de Mattos Higher Education Institute - FASERRA. Manaus-Amazonas, Brazil.

${ }^{3}$ Northern University Center - UNINORTE. Manaus-Amazonas, Brazil.

${ }^{4}$ State University of Amazonas - UEA. Manaus-Amazonas, Brazil.

${ }^{5}$ Institute of Technology and Education Galileo of the Amazon - ITEGAM. Manaus-Amazonas, Brazil.

${ }^{2}$ http://orcid.org/0000-0003-2163-2296 (iD, ${ }^{4}$ http://orcid.org/0000-0003-1669-9090 (D), ${ }^{5}$ http://orcid.org/0000-0001-6705-6971 (iD)

Email: basiliocss@gmail.com, robsonedfaria@yahoo.com.br, darleilavor27@gmail.com,novo.sanches@gmail.com,david002870@hotmail.com

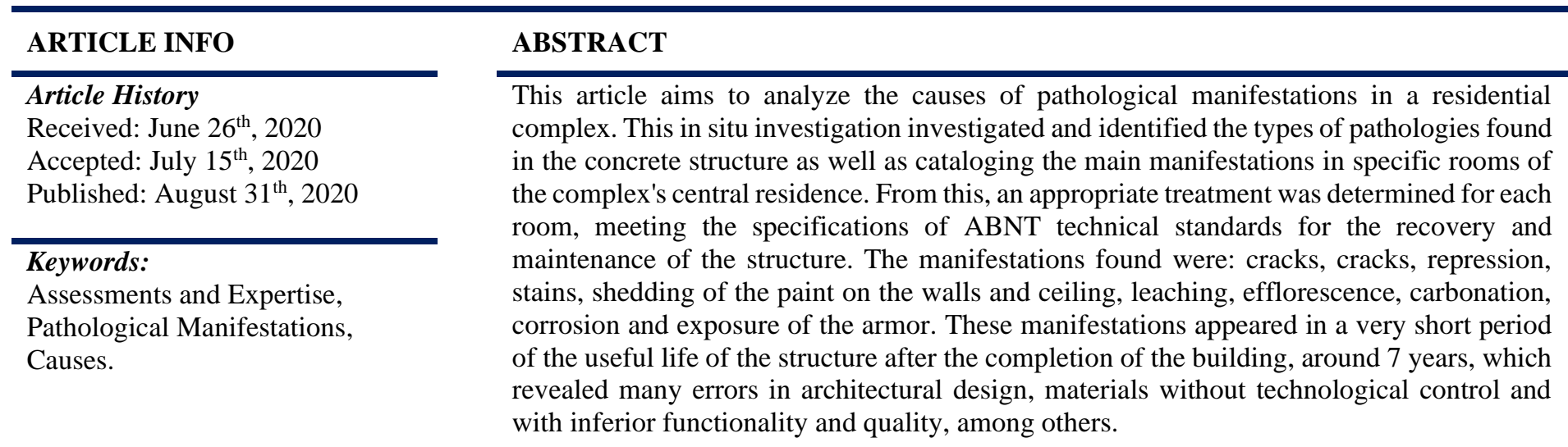

Copyright (02016 by authors and Galileo Institute of Technology and Education of the Amazon (ITEGAM). This work is licensed under the Creative Commons Attribution International License (CC BY 4.0).

\section{INTRODUCTION}

Since the beginning of human development, when man, in general, has ceased to be a nomad, he has been perfecting his construction techniques and passing his scientific knowledge from generation to generation, accumulating an extensive collection of development of new construction technologies and improving its finite structures, combining several materials that make the product more durable.

The fast-paced development of civil construction to meet a growing demand for buildings, whether they be work, industrial or housing, driven by the modernization of society itself, promoted a great scientific and technological leap [1]. A building is any type of installation whose final purpose is to provide shelter for the performance of the most varied functions of man [2]. The construction process of a building follows as follows: initial idea, prior planning, design, manufacture of materials for use on the construction site, execution of the building's component parts and use [3]. During such processes, failures or carelessness of the most varied types can occur, which end up generating addictions and constructive problems of the previously mentioned steps [2]. In developing countries, such as Brazil, socioeconomic conditions caused the works to reach ever higher execution speeds, resulting in weak controls on the materials used and services [4]. The deficient training of engineers and architects, the housing policies and inconsistent financing systems, have been causing the gradual decline in the quality of our constructions, to the point of finding buildings that, before being occupied, are already virtually condemned [4]. The housing issue in Brazil still represents a challenge for Brazilian politics. With decades without incentive programs in the segment, the country has accumulated a gigantic housing deficit among the poorest families, who sought alternatives with informal construction in peripheral areas and hills. The creation of the "My home, my life" program in 2009 tries to reverse this situation, built with years of inexistence of public policies in the housing sector [5]. The 
assessment of this situation is perhaps the main objective of the pathology of buildings, considering that this is the moment that requires technical intervention, so that it is still possible to rehabilitate the structure, postponing its useful life. It can also be said that when it comes to building performance, that if at a certain point in the useful life of a certain element it shows an unsatisfactory performance, it does not mean that it is necessarily condemned [6]. Normally, pathological problems are related to the drop in performance of buildings, this fall is directly related to the damage and constructive vices that appear in the building over time [7]. The housing problem is related to the consideration of the following parameters: quantity, quality, cost and durability [8]. Quantity is related to the housing deficit; quality encompasses other concepts such as performance and builds ability, in addition to being directly related to cost and durability. When carrying out appropriate and periodic maintenance that is part of a broader management process, it accepts the guarantee of a longer useful life and satisfactory structural and functional performance, identifying, through periodic inspections, existing faults, diagnosing them and indicating recovery actions [9]. The maintenance of structures is considered as one of the processes that make up the construction of a building, as important as the execution of it, to contribute to the absence of pathologies [6]. The part of engineering that examines the symptoms, the mechanism, the origins and the causes of failures in civil construction is defined as pathology, that is, it is the study of all the components that form the diagnosis of the problem [10]. After the appearance of pathological manifestations in a building, the problem tends to worsen rapidly, resulting in other secondary problems [11]. Pathological problems are not restricted to structures considered old. Structures that are well designed and executed, and used correctly can also perform poorly. However, with the development of knowledge of destructive processes, equipment and techniques for observing structures and taking into account the great technological evolution; it became possible to accurately diagnose most pathological problems [12]. Pathology, according to the Aurelio dictionary, is the part of Medicine that studies diseases. Like patients in medicine, buildings can also present diseases, such as cracks, stains, breaks, corrosions, cracks, among others [13]. The causes of the occurrence of pathological phenomena can be the most diverse, from natural aging, accidents, irresponsibility of professionals and users who choose to use materials outside specifications or do not perform the correct maintenance of the structure, often for economic reasons, among others [6]. The study of pathologies in buildings is of great importance in the search for quality in construction processes and in improving the habitability and durability of buildings. In order to avoid the appearance of pathological manifestations, it is necessary to make a detailed study of the origins in order to better understand the phenomenon and assist in decisions to define conduct and action plans against problems [14]. It cannot lead to the emergence of all pathological problems due to the lack of maintenance or adequate conducts by users, the emergence of pathological problems is due to a combination of errors in all phases of building design, structure efficiency, methods constructive, of the aggressive conditions of the environment, but there is a part of the users' fault for the lack of maintenance to the building [15]. In order for existing pathological manifestations to be eliminated, it is essential to conduct a detailed study of their origins [14]. This study, in addition to providing a better understanding of the mechanism involved in the phenomenon, can assist in the diagnosis of the problems encountered. These pathological manifestations need to be identified and resolved. For this, it is necessary to use analysis methods developed from theoretical and practical knowledge, in order to use them in the treatment of problems presented through the collection of relevant information and data [2]. Still adds that the lack of maintenance and lack of knowledge on the part of users about aggressive elements and about the concrete structure, such as prolonged exposure to humidity, application of aggressive products to concrete and reinforcement, can generate serious problems for the structure compromising all the work done so far in the previous stages [16]. The pathological manifestations that stand out the most in concrete are efflorescence, cracks, excessive arrows, corrosion of the reinforcement, and stains in exposed concrete, defects in landfill and compaction and problems due to the segregation of components of the concrete [3]. It is also surprising that, in general, pathological manifestations appear in a very characteristic way and with a well-established statistically occurrence [3]. Even considering that many buildings have given real examples of great durability, under totally adverse conditions, it is worth remembering that they do not have an infinite useful life.

Therefore, this article sought to submerge two important themes for civil engineering: pathological manifestations and the assessment of their supposed causes. The expert evaluation was carried out in a residential complex with vertical housing located in the neighborhood of "Square 14 of January" in the south central zone of the capital of the state of Amazonas, Manaus. The investigation tends to visualize the causes of the pathological manifestations of the central house of the complex, showing the aggressive agents that favored the appearance of the pathological manifestations, thus diagnosing the problem and considering a preventive maintenance that minimizes more appearances of these pathologies.

\section{METHODOLOGY}

Moisture is the greatest enemy of construction and the health of its occupants of a concrete structure [17]. It is against this evil that not much care is taken in the works, due to lack of knowledge of the correct solutions or lack of sense of responsibility, adopted by the negligence of the personnel in charge of the execution. It also adds that the temperature variation causes a volumetric change in the concrete structures [18]. In large concrete elements, such as dams or foundation blocks, cracks may appear due to the effects of thermal gradients caused by the heat of hydration of the cement, which can cause tensile stresses [18].

In view of these aggravating factors that are periodically common in the northern region of Brazil, with the relative humidity content ranging from $80 \%$ to $98 \%$ on hot days, this study applies some methodologies studied according to the visit of the concrete structure (residence) from which it presents pathological manifestations due to numerous factors, such as: the overload of the structure, the lack of surface drainage of the residences which causes several factors in relation to the humidity of the place, such as stains, discovery of the painting, discovery of the plaster exposing the steel frames and etc. Some information from the residents of the selected location indicated that these demonstrations were due to the large undue drainage of rainwater. However, after the on-site inspection to assess these causes, it was observed that the structure is overloaded due to a new pavement recently built (around 7 years old), from which the structure began to show many cracks and over time. Months it 
evolved into cracks or cracks, efflorescence and leaching, as well as the detachment of concrete from the steel frame (corrosion caused by carbonation). After these identifications, the possible causes of the manifestations found in that residence were analyzed. The studied residence is located on Avenue Tefé, "Square 14 of January" neighborhood, in the south central area of the Amazon capital - Manaus, in the basement 1. This residential has two upper floors and two basements. The entire survey study of the site had a period of 15 days in the rainy season (December to May) and another 15 days in the Amazonian summer period (June to November) for the evaluation of both the structure and the pathological manifestations already evident in the site. The study of the soil was not possible due to the location around the residence, which is paved with concrete. But due to the fact that it is a land near a stream (stream), it is concluded that in the vicinity of the land there is a humid material (soil) where it was observed in a vacant land, some $200 \mathrm{~m}$ (meters) close to the complex, it was noted that the soil is superficially very dark with a lot of organic material, with a high vegetation and solid urban waste (MSW) piled up, possibly thrown by neighboring residents.

The main concern of the study of pathologies that occur in civil construction is the knowledge of the causes of the problems and how to avoid them [19]. Through some studies you can have an idea about its causes. For the treatment of pathologies effectively, it is necessary to identify the causes that generated the non-compliance. When specifying materials and components, the designer must know their durability, either to assess whether they will meet the minimum desired performance, or to compare overall costs, which include maintenance and operating costs, as well as the protection of service life [20]. [19] Affirms that without due attention to these factors, several problems can be generated, with, for example, the low quality of specific materials, the specification of incompatible materials, insufficient or mistaken detailing, unworkable constructive detailing, lack of standardization and dimensioning errors, compromised performance and the overall quality of the built environment.

\section{MATERIALS AND METHODS}

\section{III.1 STAINS}

Moisture in buildings is one of the most frequent and most difficult problems to be dealt with in the field of civil engineering. Not only due to the complexity of the phenomena involved, but also to the problems related to construction flaws, mainly waterproofing. This problem is often associated with others, which makes its treatment even more difficult [2].

The appearance of stains in reinforced concrete buildings is usually influenced by excess moisture or highly porous structures where the weather ends up infiltrating under them causing the structure to expand. Below, the causes of the types of humidity in a building are listed, according to [21]:

- Rain moisture - caused specifically by the action of rain;

- Construction moisture - caused due to the porosity of materials, such as: concrete, bricks, structural blocks, mortars, paints and etc.;

- Condensation humidity - caused by the high moisture content of the air combined with a cold surface or not;

- Capillarity humidity - resulting from the capillarity absorption of water existing in the soil by the foundations of the walls and floors up to the facades and floors;

- Accidental humidity - arising from failures in the distribution piping and / or water collection systems of the construction.
Figure 1, below, shows stains all over the kitchen wall as well as details the detachment of the painting from both the wall and the ceiling (slab). The kitchen is located under the service area of the residence on the first floor where there is no gutter or water drainage pipe as shown in Figure 2, below.

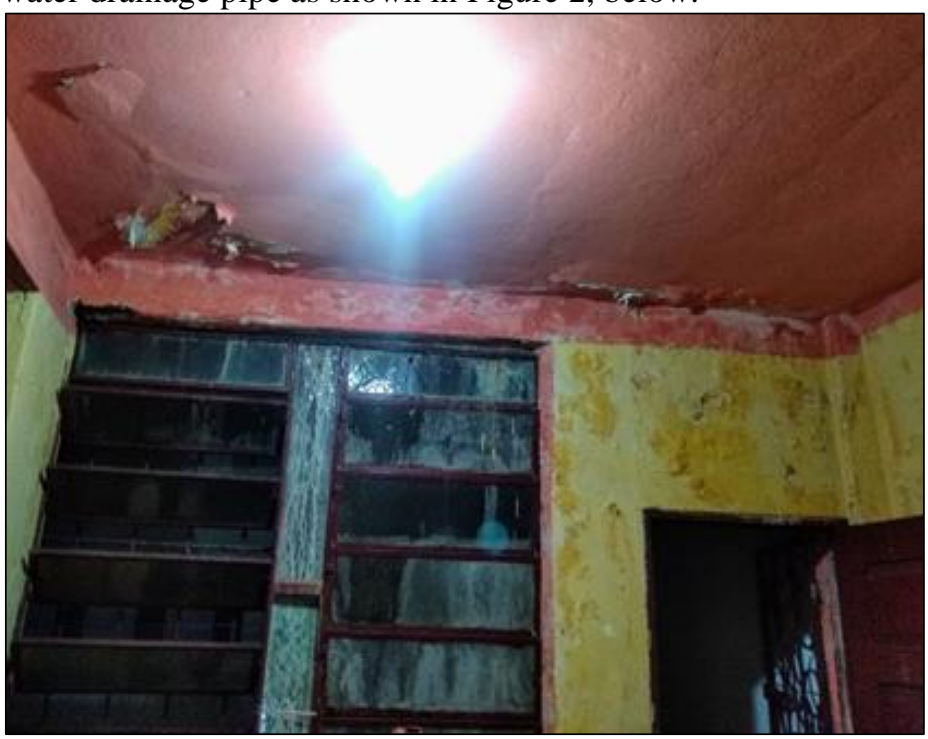

Figure 1: Stains and paint detachment on the kitchen wall of the residence under evaluation.

Source: Authors, (2020).

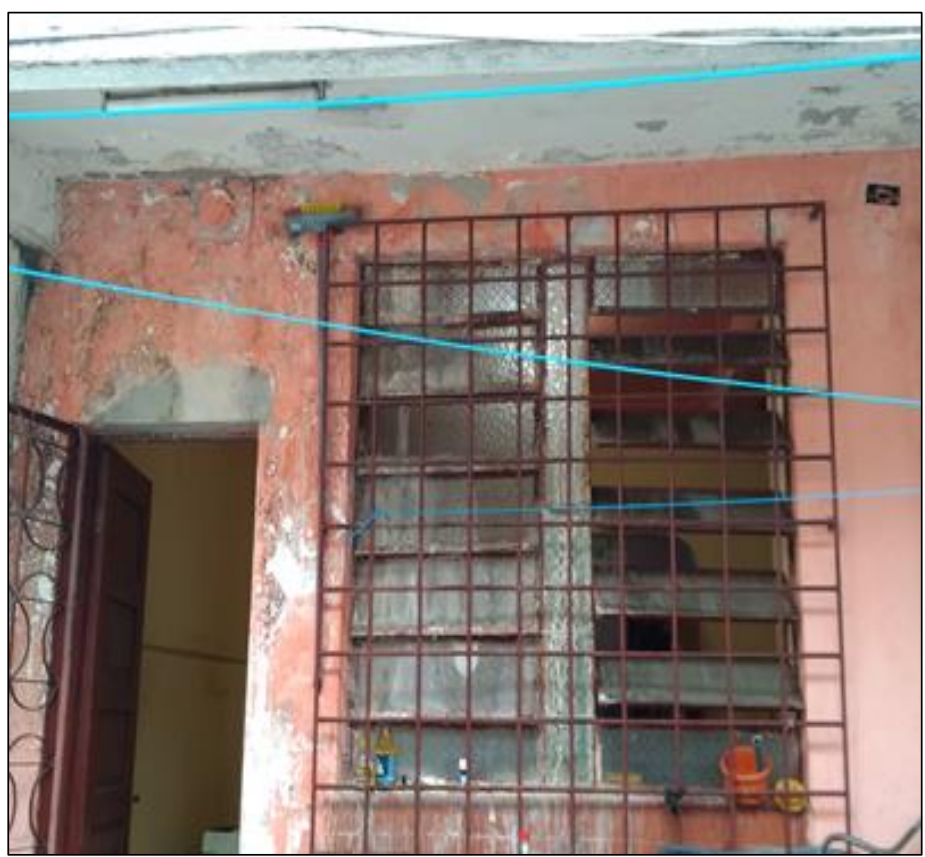

Figure 2: External area of the kitchen wall where the service area of the current residence is located.

Source: Authors, (2020).

\section{III.2 REPRESSION}

Repression is excess weight, the accommodation of the building, the weakness of the material or the terrain causes the piece to deform or sink [22]. All soils are subject to repression, greater or lesser, depending on the conditions of the soil and groundwater [23]. Repression is the main cause of cracks and cracks in buildings, especially when differential repression occurs, that is, part of the work lowers more than another, generating unforeseen structural efforts and may even lead the work to ruin [19]. 


\section{III.3 FISSURES}

Fissures can be caused by a multitude of pathological manifestations, below [2]; one of the main causes is listed.

- Cracks cause by misture;

- Cracks caused by chemical changes in construction materials.

Cracks, as they are also known to cracks, can start to appear immediately in the architectural design of the building, which is generally related to the designer's lack of knowledge about the properties of the materials used in the work. Incompatibility between architectural, structural and foundation projects usually leads to stresses exceeding the material's resistance limits, thus creating cracks [24].

Second [25] among the pathological problems that affect buildings, cracks are particularly careful because:

a) They serve as a warning for a possible dangerous state of the structure;

b) They may cause the performance of the work in use to be compromised (water tightness, durability, acoustic insulation, etc.);

c) Psychological constraint to users.

In Figure 3, below, it shows one of the many cracks in the bathroom of the residence caused by repression in the structure.

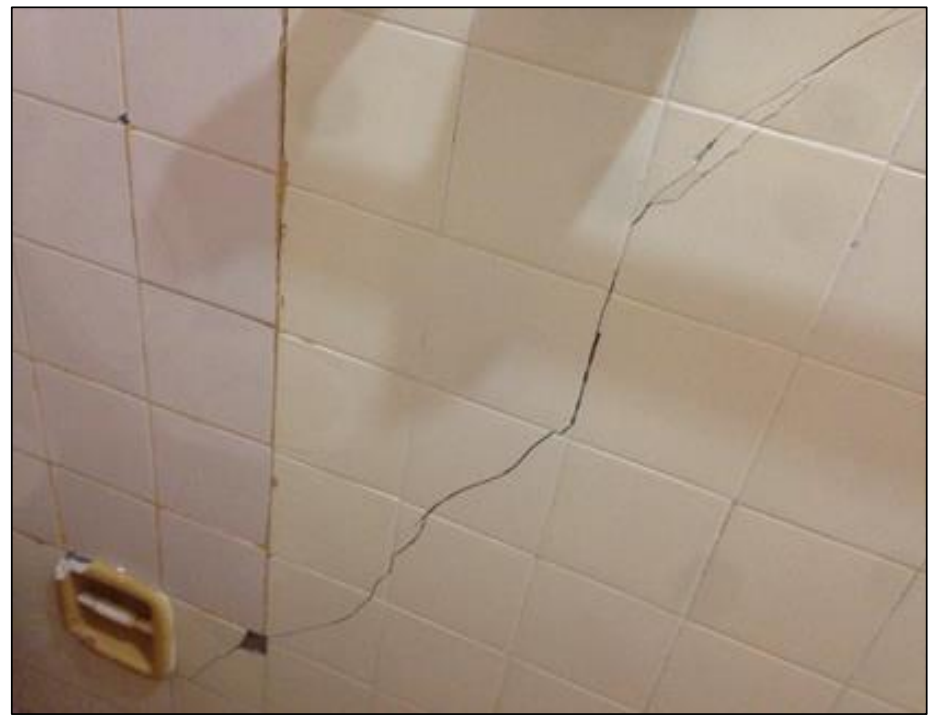

Figure 3: Crack in the bathroom wall caused by repression of the structure.

Source: Authors, (2020).

\section{III.4 LEACHING AND EFLORESCENCE}

In civil construction, efflorescence, popularly known as saltpeter, is usually the name given to salt residues, which after having been diluted with water and passed through the building material by the capillary effect are recrystallized from the surface of the walls, then the water becomes evaporates and reaches the surface. These soluble salts may already exist on the building site or in the building materials of the wall. As in civil construction many of the materials used are hygroscopic, that is, they have the ability to absorb moisture from the air, the pathological manifestations of efflorescence are a very common phenomenon in everyday life [3].

For the reaction to occur, the presence of cement, water and soluble sulfates is necessary. For this reason, the joint use of cement and plaster is dangerous. One of the main causes of efflorescence is, therefore, the soluble salts found in raw materials.
Acid water or water with a high concentration of chlorides and sulphates, when it enters the capillary pores of the concrete, dissolves the calcium hydroxide from the cement paste, which can later react with the carbon dioxide in the air to form carbonate and calcium $\left(\mathrm{CaCO}_{3}\right)$. This salt when carried by the water and is deposited on the surface of the coating layer, forming a white stain or stalactites, giving an undesirable aesthetic to the construction [3].

In Figure 4, below, one of the leaching processes is shown, which in this case is the thick white stain forming a foam in the external pipe that comes from the floors above.

In Figure 5, below, it shows a case of efflorescence in a semi-open hole in the slab in the service area of the house in evidence. It is noted that the pathological manifestation covering the whole orifice with drool and whitish spots is quite aggravated. It is also observed that the drool has an orange tint showing that the metallic structure is exposed.

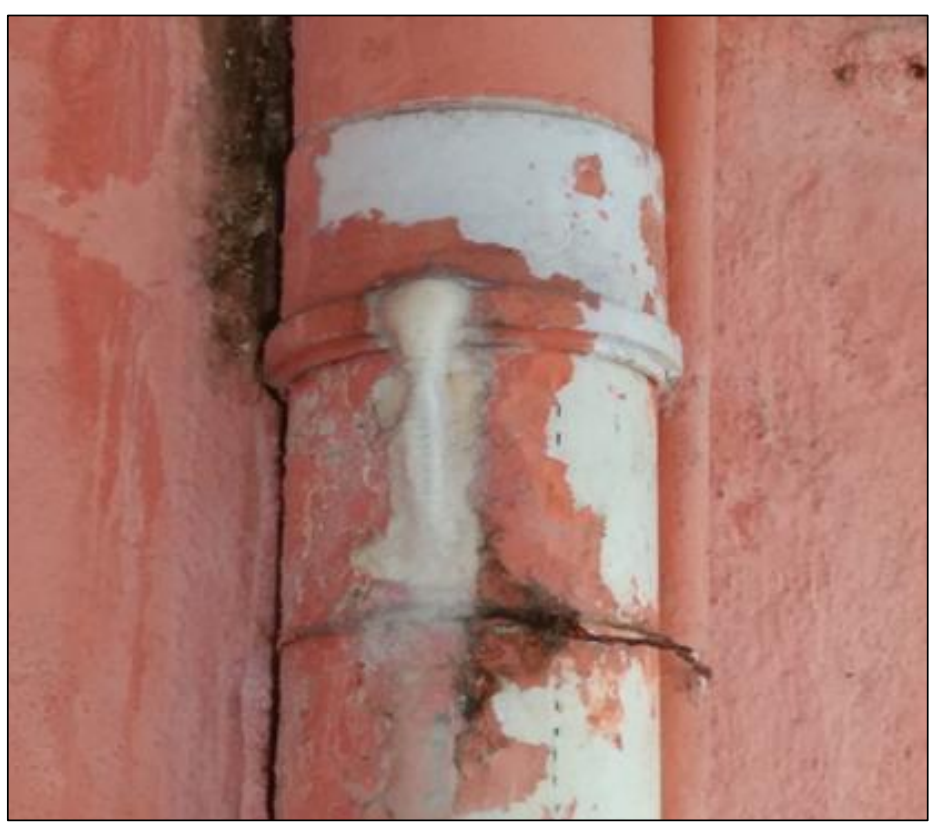

Figure 4: Leaching in the external piping of the service area. Source: Authors, (2020).

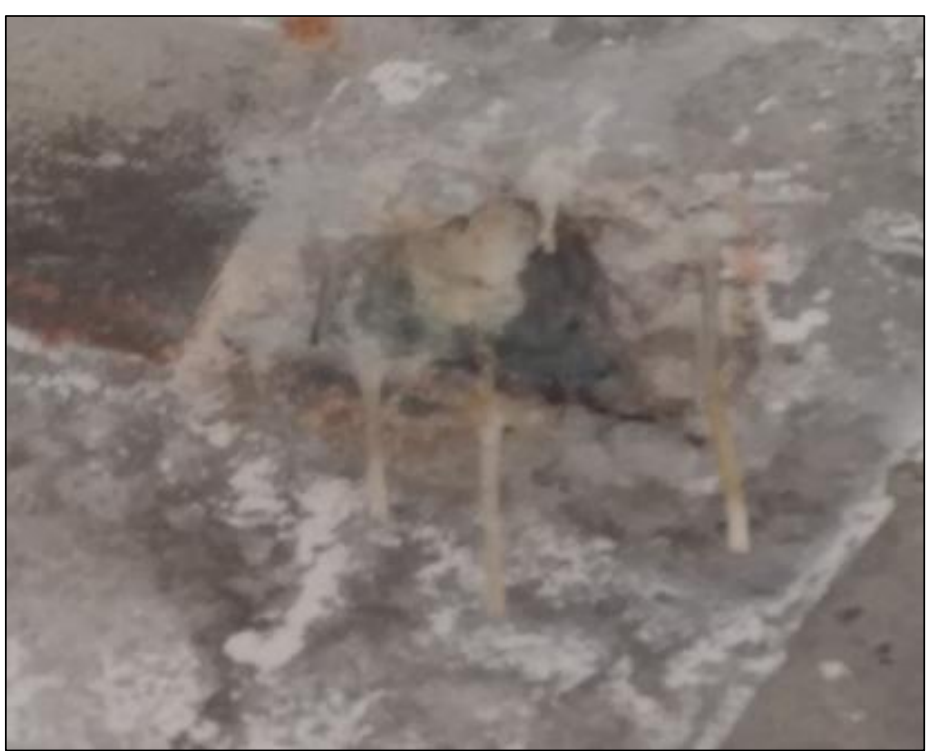

Figure 5: Efflorescence and leaching in the semi-open hole in the service area slab.

Source: Authors, (2020). 


\section{III.5 CORROSION AND THE CARBONATATION PHENOMENON}

It states that corrosion and deterioration can be associated with mechanical, physical, biological or chemical factors [26].

Carbonation is the chemical reaction of hydrated cement compounds with carbon dioxide in the air. This carbonation reaction in cementations composites is a widely studied topic, especially in concrete due to the effect of depassivating the reinforcement of reinforced concrete structures, which initiates the process of oxidation and corrosion of steel. In this context, carbonation is understood as a harmful process to structures [27]. The carbonation process occurs due to the reactions of $\mathrm{CO}_{2}$, present in the air, with the alkaline hydroxides present in the material. This occurs especially with calcium hydroxide, in an aqueous medium, forming calcium carbonate and reducing the $\mathrm{pH}$, initially around 13 , to values close to 8 [28].

Carbonation is one of the main causes of corrosion or deterioration of a reinforced concrete structure, especially in countries like Brazil with the tropical climate and specifically in places where $\mathrm{CO}_{2}$ emission interacts with the relative humidity content of the air, such as in the northern region from the country.

In Figure 6, below, it shows the corrosion process and the detachment of the concrete metal reinforcement caused, possibly by the carbonation effect, where a part of the structure was exposed, being vulnerable to pathological manifestations.

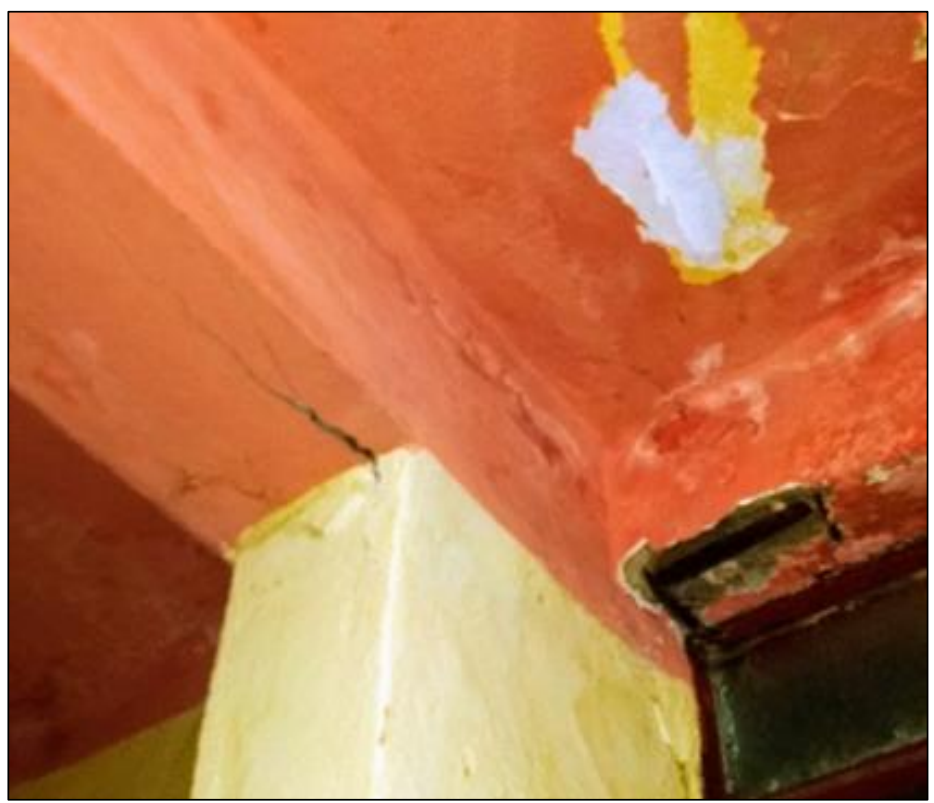

Figure 6: Corrosion caused by the effect of carbonation on the reinforced concrete structure.

Source: Authors, (2020).

\section{RESULTS AND DISCUSSIONS}

Determining the causes of anomalies in residential buildings is a very complex and extremely difficult task. It is not always possible to identify a cause in a unique and clear way, given, for example, the wide variety of elements and materials that make up the building, the multiple functions that the various parts of a building play and the elements of construction that integrate it, the complexity of the environment that involves the building and the different types of activities of its users, and the simultaneous performance of the various causative agents [29]. It states that anomalies can present several symptoms, which can rarely have a single cause, but which can generally have several causes that occur simultaneously or in sequence with the accumulation of effects over time [30]. Therefore, the same cause can cause different pathologies and, on the other hand, different symptoms. There are no predefined rules or procedures for determining the causes of an anomaly. Each case is a case and should be analyzed as such.

The following sections present the pathological manifestations found at the research site and, according to some authors specified in the scope of this research, demonstrate what caused these manifestations in this residence.

\section{IV.1 ON PATHOLOGICAL MANIFESTATIONS}

The form of manifestation of this problem and the nature of the humidity [21]. It emphasizes that the accumulation of fungi in the covering layers, be it of the most varied types, generate colonies that feed on organic materials [31]. The ideal places for their proliferation are areas that have condensation moisture and that there is no running water. This type of pathology can be caused by several factors, including hydrothermal variation.

Despite the fact that the residence is well ventilated and the side walls diagnosed with pathological manifestations where the afternoon sun is intense, the water that comes from the upper floor would have to be drained with an external pipe that went to the sewers in order to stop the constant flow of water. Water on these walls and thus not seeping into the soil causing a possible expansion in the reinforced concrete structure, even if it is thermal as well as functional.

The waterproofing of these structures is also a viable alternative both in the appearance of new manifestations and in the interruption of the aggravation of the manifestations that are in the place.

In order to avoid corrosion due to carbonation within the service life, concrete structures are required to have a concrete covering with sufficient thickness and resistance against carbonation [32].

Temperature plays a dual role in deterioration processes. If on the one hand it causes an increase in the rate of corrosion and ion mobility, on the other hand the decrease can give rise to condensation, creating local increases in the moisture content [33].

The detachments are characterized by the loss of adhesion of the substrate's ceramic plates, or of the adhesive mortar, when the stresses arising in the ceramic coating exceed the adhesion capacity of the connections between the ceramic plate and the adhesive mortar and/or plaster [34].

\section{CONCLUSION}

It is important to know the micro climate in which the building is located [35]. Due to the way and the intensity that the rain acts on each of the facades, they must be designed differently, the most affected by the action of rain with greater tightness.

In this case, the lack of maintenance and the lack of drainage in the residential complex are the main causes of pathological manifestations, which can lead to a collapse very soon. Given the facts studied, it is concluded that:

a) All the results obtained in this study were very successful as well as tireless research to obtain all the assessments of the causes of pathological manifestations on the spot;

b) The site under study is in urgent need of maintenance and meticulous attention so that it does not affect the other residences of the complex causing a tragedy; 
c) The cracks and cracks found in the residence under study were caused due to the settlement where the structure sank due to excess weight in the soil where it is notable that the foundations chosen at the time of construction are not suitable for this complex;

d) The waterproofing of the affected areas will stop the growth and the appearance of new pathological manifestations in the structure of the complex;

e) For the exposed areas of the reinforcement of the reinforced concrete structure, it is suggested that they be treated and covered with the appropriate ABNT specifications.

Therefore, the expert assessment was meticulously investigated.

\section{REFERENCES}

[1] T. d. S. AMBRÓSIO, "Patologia, tratamento e reforço de estruturas de concreto no metrô de São Paulo," Trabalho de conclusão de curso: São Paulo, 2004.

[2] P. A. B. Zuchetti, "Patologias da construção civil: investigação patológica em edifício corporativo de administração pública no Vale do Taquari/RS," 2016.

[3] P. R. HELENE, "do Lago," Manual de reparo, proteção e reforço de estruturas de concreto. São Paulo, Red Rehabilitar, 2003.

[4] É. THOMAZ, "Tricas em Edifícios: Causas, Prevenção e Recuperação. $1^{\mathrm{a}}$ Edição," Editora PINI. São Paulo, 1989.

[5] AZEVEDO, Gabriela. Minha Casa, Minha Vida prevê 700 mil novas moradias para 2014. <http://www.jb.com.br/pais/noticias/2014/01/19/minhacasa-minhavida-preve-700-mil-novas-moradias-para-2014/>. Accessed March 2020

[6] V. C. M. de Souza and T. Ripper, Patologia, recuperação e reforço de estruturas de concreto: Pini, 1998.

[7] P. O. DO CARMO, "Patologia das construções," Santa Maria, Programa de atualização profissional-CREA-RS, 2003.

[8] P. R. B. de Lima, "Consideração do projeto no desempenho dos sistemas construtivos e qualidade da edificação-proposição de um modelo de banco de dados," 2005.

[9] A. VITÓRIO, "Fundamentos da patologia das estruturas nas perícias de engenharia," Recife: Instituto Pernambucano de Avaliações e Perícia de Engenharia, 2003.

[10] P. R. Helene, M. Gerschenstein, P. S. F. de Oliveira, and F. A. de Guimarães, Manual para reparo, reforço e proteção de estruturas de concreto: Pini, 1992.

[11] B. F. Hirt, "Manifestações patológicas em obras de escolas públicas estaduais do Paraná," 2014.

[12] DOS SANTOS, C. F. Patologia de estruturas de concreto armado. Trabalho de conclusão de curso (Graduação em Engenharia Civil) - Universidade Federal de Santa Maria, Rio Grande do Sul. 2014. 91p. Available in:< http://coral.ufsm.br/engcivil/images/PDF/2_2014/TCC_CAMILA\%20FREITAS\% 20DOS\%20SANTOS.pdf>. Accessed March 2020.

[13] L. C. IANTAS, "Estudo de caso: análise de patologias estruturais em edificação de gestão pública. 2010. 58 f," Monografia (Especialização)-Curso de Curso de Pós Graduação em Construção de Obras Públicas, Universidade Federal do Paraná, Curitiba, 2010.

[14] D. Nazario, "Manifestações das patologias construtivas nas edificações públicas da rede municipal de Criciúma: inspeção dos sete postos de saúde," 2012.

[15] A. A. Bertini, J. C. Martins, and E. Thomaz, "Desempenho de edificações habitacionais: guia orientativo para atendimento à norma ABNT NBR 15575/2013," 2013.

[16] A. A. de Amorim, "Durabilidade das estruturas de concreto armado aparentes," 2010 .

[17] C. Schönardie, "Análise e tratamento das manifestações patológicas por infiltração em edificações," Trabalho de Conclusão de Curso de Engenharia Civil. Universidade Regional do Noroeste do Estado do Rio Grande do Sul. Ijuí, 2009.
[18] R. M. Ferreira, "Avaliação de ensaios de durabilidade do betão," 2000.

[19] A. P. SOUSA, "LEVANTAMENTO DE PATOLOGIAS EM OBRAS RESIDENCIAIS DE BAIXA RENDA DEVIDO À AUSÊNCIA DE CONTROLE TECNOLÓGICO DE MATERIAIS," 2014.

[20] P. S. Dunston and C. E. Williamson, "Incorporating maintainability in constructability review process," Journal of Management in Engineering, vol. 15, pp. 56-60, 1999.

[21] E. J. VERÇOZA, "Patologia das edificações," Porto Alegre, Editora Sagra, p. p172, 1991.

[22] ZARE ENGENHARIA E MANUTENÇÃO. Patologias. Artigo, 2018 Available https://www.zareengenharia.com.br/patologias/\#: :text=RECALQUE\%3A\%20o\% 20 excesso $\% 20 \mathrm{de} \% 20$ peso, as $\% 20$ pe $\%$ C $3 \%$ A 7as $\% 20$ podem $\% 20$ nascer $\% 20$ fracas. $>$. Accessed March 2020

[23] G. OLIVARI, "Patologia em edificações," São Paulo, p. p95, 2003.

[24] LOTTERMANN, A. F. Patologias em estruturas de concreto: estudo de caso. Trabalho de conclusão de curso (Graduação em Engenharia Civil) - Universidade Regional do Noroeste do Estado do Rio Grande do Sul, Itajaí, Rio Grande do Sul. 2013. 66p. Available in: https://bibliodigital.unijui.edu.br:8443/xmlui/bitstream/handle/123456789/2133/T RABALHO\%20TCC2\%20FINAL\%20ANDRE\%20F\%20LOTTERMANN.pdf?se quence $=1>$. Accessed March 2020

\section{[25] F. D. L. ANTONINO, "TRINCAS EM ALVENARIAS DE VEDAÇÃO OU} CONVENCIONAL," 2019.

\section{[26] GENTIL, Vicente. Corrosão. 6ª ed. Rio de Janeiro: LTC, 2014. 360p.}

[27] BRANDÃO, G. B.; SOUZA, R. B. Efeito do empacotamento de partículas da fase matriz na carbonatação de compósito cimentício. Anais. 2015. Instituto Brasileiro de Concreto. Bonito. Mato Grosso do Sul.

[28] A. Bentur, N. Berke, and S. Diamond, Steel corrosion in concrete: fundamentals and civil engineering practice: CRC press, 1997.

[29] J. V. Paiva, J. Aguiar, and A. Pinho, "Guia técnico de reabilitação habitacional," Laboratório Nacional de Engenharia Civil e Instituto Nacional da Habitação, Lisboa, 2006.

[30] D. Leitão and M. G. d. Almeida, "Metodologia para a implementação de check lists em intervenções de reabilitação," 2004.

[31] M. Pintan, "Manifestações patológicas e estudos da corrosão presentes em pontes do recife," Dissertação do curso de mestrado em Engenharia Civil Universidade de ..., 2013.

[32] J. Visser, "Influence of the carbon dioxide concentration on the resistance to carbonation of concrete," Construction and Building Materials, vol. 67, pp. 8-13, 2014.

[33] O. Cascudo, "Controle da Corrosão de Armaduras de Concreto, 1a," Ed., Editora PINI Ltda., S. Paulo, 1997.

[34] A. Fontenelle and Y. d. Moura, "Revestimento cerâmico em fachadas-estudo das causas das patologias," Relatório de pesquisa, Comunidade da ConstruçãoSistemas à base de cimento, Fortaleza. Disponível em:< http://www.abcp.org br/comunidades/fortaleza/arquivos/03_PesquisaPa tologia.pdf $>$. Acesso em, vol. 17,2004

[35] A. R. PEREZ, "Umidade nas Edificações: recomendações para a prevenção de penetração de água pelas fachadas," Tecnologia de Edificações, São Paulo. Pini, IPT-Instituto de Pesquisas Tecnológicas do Estado de São Paulo, Coletânea de trabalhos da Div. de Edificações do IPT, pp. 571-78, 1988. 